\title{
Remembered: Zofia Rydet in the Biographically-Oriented Perspective of the Sociology of Art
}

\author{
Tomasz Ferenc \\ University of Lodz, Poland
}

DOI: https://doi.org/10.18778/1733-8069.17.3.11

\section{Keywords:}

Zofia Rydet, artist,

photography, art,

biography, fieldwork,

mythologization

\begin{abstract}
Zofia Rydet is one of the most outstanding Polish and even European artists of the second half of the 20th century. She left a huge artistic legacy, but her biography still in many respects remains a mystery. The memory of a great artist is often mythologized, and the interpretation of the work after his/her death begins to separate from the original intentions of the creator. These are processes of great interest to art historians and sociologists alike. They can be studied by adopting the methods of the biographically-oriented sociology of art. This article uses some of these methods, namely the analysis of the existing documents, archival research, and interviews. The analysis of the collected material has revealed how Rydet was remembered by those who had the opportunity to meet her, accompanied her during field trips, and talked with her about art and photography. The aim of such research is to try to get to know the artist better, as well as to understand her work and the social functioning in what was a very specific time and environment.
\end{abstract}

Tomasz Ferenc, employee of the Department of Sociology of Art, University of Lodz. His research interests include anthropology and visual sociology, studies of migration processes, and biographically-oriented sociology of art. Recent publications: T. Ferenc, K. Jóźwiak, A. Różycki, Zapisy pamięci. Historie Zofii Rydet (University of Lodz Press, 2020); T. Ferenc, M. Domański, Borderlands: Tensions on the External Borders of the European Union (Wydawnictwo ASP in Lodz, 2019).

\section{Contact details:}

\section{Katedra Socjologii Sztuki}

Wydział Ekonomiczno-Socjologiczny, Uniwersytet Łódzki ul. Rewolucji 1905 r. nr 41/43, 90-214 Łódź

email address: tomasz.ferenc@uni.lodz.pl

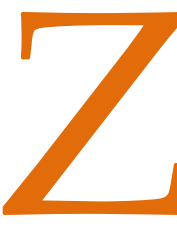
ofia Rydet is considered one of the most outstanding Polish artists of the second half of the 20th century. Her immense creative output, despite its extremely varied nature, is a consistently developed artistic project, in which key themes are recurring. Regardless of whether Rydet used a document or surrealistic convention in her work, whether she used the so-called straight photography, made collages, or portrayed elderly people or children, the key issue was the very human existence, memory, and transience. Her attention was concentrated on what was inevitably nearing the end of its existence and what, in her opinion, 
should be preserved in some way. Photography became her way to preserve it while her belief in the power of photographic image was of a truly mystic character.

Zofia Rydet was born in 1911 in Stanisławów, in the areas that are now part of western Ukraine, while before World War II they had belonged to the Second Polish Republic and had been called the Borderlands. The artist's family was connected to the strict elite of the city. Rydet's father, former Piłsudski's legalist, lieutenant colonel, was a lawyer with the soul of an activist, ready to support those who could not afford to hire an attorney. Her older brother Tadeusz, from whom she took over her passion for photography, ran the Orbis travel agency in Stanisławów. Apart from possessing the house in the city, the family owned a summerhouse in the heart of the Gorgan Mountains, in the town of Yaremche. Young Zofia Rydet quickly began to take over her artistic talents, but she was transferred to the Lviv Academy of Arts and graduated from the Private Institute of Rural Farming in Snopków near Lviv. In 1933, she obtained a diploma of a business school teacher and started working in this profession at the business school in Stanisławów. In 1935, she switched to travel agency. During this time, she not only began to visit Galicia, but also traveled around Europe (Jóźwiak, Ferenc, and Różycki 2020:68). In a film devoted to the artist and made by Andrzej Różycki, Zofia Rydet describes the pre-war period of her life as extremely happy. ${ }^{1}$ The outbreak of the war marked the end of this stage of her life. The

\footnotetext{
${ }^{1}$ Andrzej Różycki's 1989 film titled Nieskończoność dalekich dróg. Podpatrzona i podstuchana Zofia Rydet (The infinity of distant roads...) has become the most significant source of information and knowledge about the artist. At the same time, it is known for being a very important Polish documentary devoted to art and photography in general.
}

subsequent Soviet, German, and Hungarian occupations, and the escalation of the military operations of the UPA (Ukrainian Insurgent Army) - directed against Polish citizens - impacted the entire Rydet family. The artist's father and brother barely escaped imprisonment by the Soviet NKWD services and German purges among the Polish intelligentsia. In Stanisławów, the terror of war took on a particularly strong and brutal form. Shootings, arrests, deportations, and public executions became the everyday life of the occupied city. ${ }^{2}$ In 1944, the whole Rydet family managed to leave for Rabka, a city in southern Poland, almost 500 kilometers from Stanisławów. Thousands of Poles who left Kresy (former Eastern Borderlands of the Second Polish Republic) and went deep into Poland or to the so-called recovered lands, which were incorporated into the territory of the state in 1945 after the Yalta and Potsdam conferences, were forced to set out on a similar journey. The post-war fate of Zofia Rydet led her through Bytom, where she ran a haberdashery shop for a short time, to Gliwice, where she settled until her death in 1997. She began to engage with photography in a serious manner in 1951, and her commitment and talent soon led to her being accepted into the Gliwice Photographic Society. As a result of her moving to Gliwice in the 1960s, she started working at the University of Technology as a lecturer in photography. At that time, she was already an artist recognized in the Polish photographic community. In 1965, her first album titled Little Man was released. Since then, Rydet made her subsequent photographic series: The Time of Passing, Transformations, The World of Feelings and Imagination, The Infinity of Far Roads, and the monumental Sociological Record. She began

\footnotetext{
${ }^{2}$ The description of the war horror in the occupied Stanisławów can be found in the book by an outstanding Ukrainian author Jurii Andruchowicz (2019).
} 
creating the last of these cycles at the age of 67 and continued it for the next 12 years. The main core of the artist's magnum opus consisted of images of towns and villagers portrayed most often inside their homes. The whole thing is formally consistent in terms of composition; the majority of the photos have the subjects positioned in the center of the wide-frame, while the real depth of field was achieved by using flash. ${ }^{3}$

"The artistic and documentary project of the Polish artist is stunning with its volume, and thus also its universality" (Dziewit and Pisarek 2020:41). And although it was carried out both in urban and rural areas, both at home and abroad, it remains a great portrayal of the Polish countryside, one depicting an inevitably dying world that disappears along with the processes of progressive modernization. ${ }^{4}$ During the production of the Sociological Record, Rydet took nearly 30,000 photos, many of them still in photographic negatives. Today, despite the vast and diverse legacy of the artist, this very cycle has become her trademark, often regarded by critics as the most important work in her output. Therefore, one can say that she is an artist of a complex biography and extraordinary artistic achievements, but also still very (present) vivid in the memory of people who knew her personally. It was the memory of the artist that became the subject of this article's author's research, the course and results of which will be discussed below. ${ }^{5}$

\footnotetext{
3 The works can be seen at: zofiarydet.com/zapis/pl/pages/ sociological-records/intro. The site has been systematically developed by the Zofia Rydet Foundation.

${ }^{4}$ The analysis of this aspect of Zofia Rydet's work can be found in the book by Jakub Dziewit and Adam Pisarek (2020).

${ }^{5}$ The complete report from the research is published in the book titled Zapisy pamięci. Historie Zofii Rydet (Jóźwiak, Ferenc, and Różycki 2020).
}

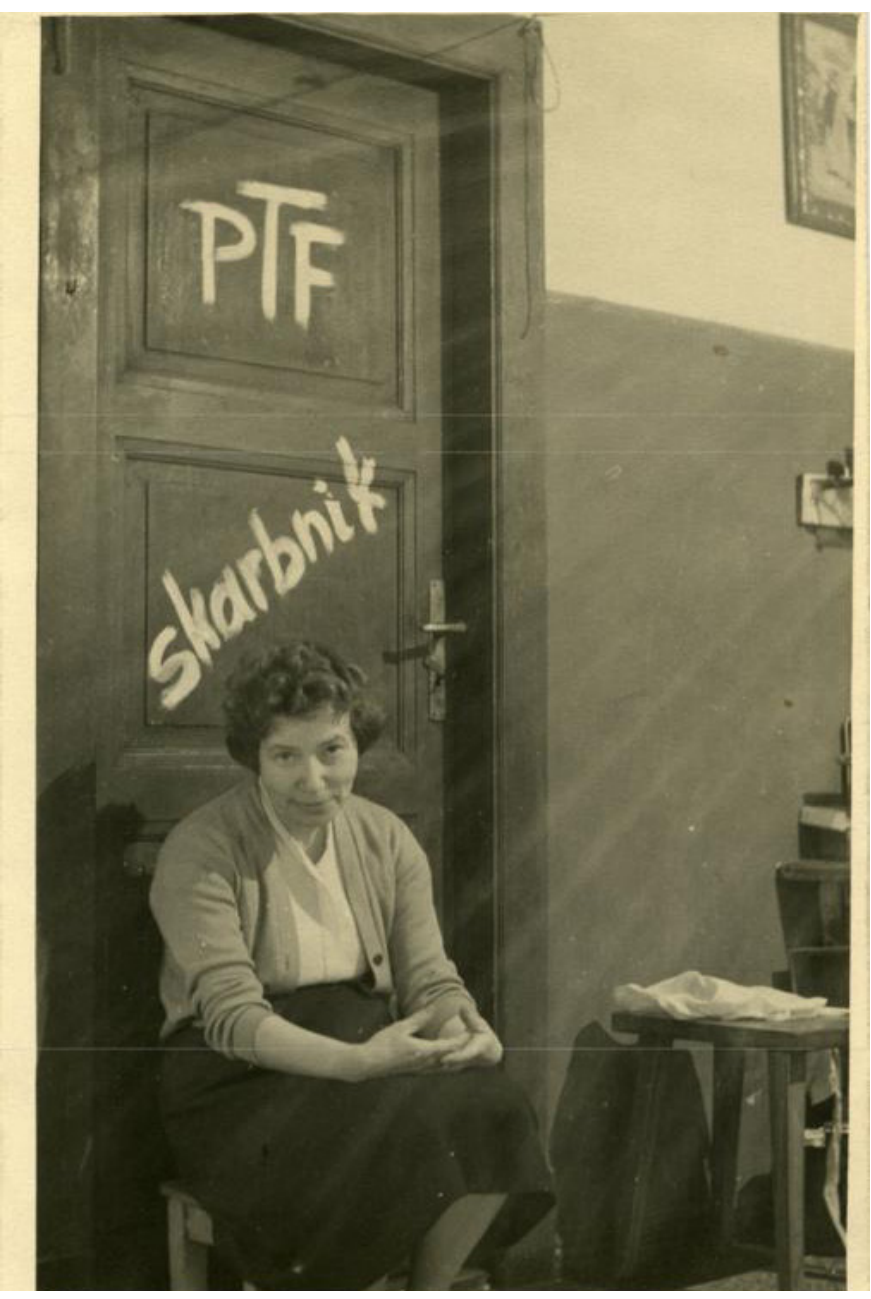

Source: Zofia Rydet, 1950s/1960s, author unknown, from the archive of the Zofia Rydet Foundation

\section{The biographically-oriented sociology of art}

The phrase: 'life and works' often appears in biographical notes on artists. As a rule, authors assume that one is connected with the other in a necessary, permanent, and undeniable way. In the biographies of artists, authors are looking for a key to understand their works, and do so by analyzing the fate of artists, getting closer to the essence of the creative process, the style, and the method of work, as well as looking for reasons for choosing the topics undertaken by the artist. In the case of outstanding artists, this phenomenon seems to be 
intensifying, which results, among other things, from the belief in their unique, almost supernatural talents. Authors thus reflect on the mystery of individual conditions and predispositions of being an artist, look for the social factors influencing the formation of a creative personality, and try to discover the mechanisms behind the success of some artists and the failure of others (Ferenc 2014:91100). The key to understanding the phenomenon of a creative personality is looked for, both in the artist's works - marked by a certain individuality - and in his/her unique life. Biographers try to define the influence of the family, social environment, education, and upbringing; they analyze the impact of historical factors on the artists' lives. ${ }^{6}$

However, in the perspective of the biographically-oriented sociology of art, adopted for the purposes of this text, the author/biographer does not seek the key to interpreting the work in the artist's life, or at least it is not the main or the only goal. What matters is sociology in the context of a human being, i.e. a social unit conditioned by a number of environmental and historical factors, and making an effort to be an artist and to implement his/her work. This type of reflection can be practiced in several ways by referring to various existing and evoked data. First of all, these can be the existing materials, such as letters, notes, diaries, published and unpublished texts, interviews with artists, video recordings, and film productions from various archives (nowadays also blogs, photo and video blogs, original websites). In the case of Zofia Rydet, there is access to each of these 'traditional' materials, as the Zofia Rydet Foundation made most

\footnotetext{
${ }^{6}$ A fine example of sociology understood this way is the analysis of the biography of Mozart, conducted by Norbert Elias (2006), who stressed the role of the composer's father in shaping Mozart's personality and career. The author also pointed to class differences that Mozart had to face throughout his entire life.
}

of them available. ${ }^{7}$ The second possibility is for the researcher to call up the data by interviewing the artists; these can be free-narrative or biographical interviews. ${ }^{8}$ Such an interview was never conducted with Zofia Rydet. This does not mean, however, that at the end of the artist's life no attempts were made to engage in such talks. It was mentioned by Jerzy Lewczyński, among other authors. "During our conversations, we repeatedly persuaded Zosia to provide us with explanations and comments on her work. She constantly replied that it would be possible when she gets better. She was becoming more and more suspicious" (Lewczyński 1999:18). The third possibility refers to the study of collective and individual memory. The socially-functioning image of a deceased artist usually consists of three main components: an artistic achievement recorded in the form of various critical and memoir studies, the biography, and memory of people who can testify. The first two elements are objectified, as they circulate in various ways and are more or less available. Memory remains in the subjective sphere and it must be evoked in the course of an appropriate interactive situation; if it is to be the subject of research, it should be recorded in the traditional way. It was this third possibility that was used in the study devoted to the memory of Zofia Rydet.

\section{Memory of the artist as an object of reflection}

The article analyzes the memories of the respondents, who were related to Zofia Rydet. For this reason, it is justified to refer to the concept of social memory, which Marian Golka defined as socially-created,

\footnotetext{
${ }^{7}$ For more information, see the Zofia Rydet Foundation's Website at http://fundacjarydet.pl (accessed: 12.09.2020).

${ }^{8}$ The theme of the biographical narrative interview is present in multiple texts, among others in authors such as Marek Prawda, Gabriele Rosenthal, or Kaja Kaźmierska.
} 
relatively unified and accepted knowledge relating to the past of a given community, assuming various forms, fulfilling various functions, and reaching the consciousness of individuals from various sources (2009:15). This knowledge is passed on orally and through various cultural products, which the author of this article would classify as the most important texts and images. Importantly, social memory is unified through the influence of the mechanisms of social life, and thus the images of a given group relating to the past become relatively similar. The concept of memory in the social context has been referred to with several terms, e.g. group memory, collective memory, or historical memory. Collective memory includes all past events that took place during the period of the group. Defining collective memory, Andrzej Szpociński writes that "it is what remains from the past in the experiences of group members or what they make their past - a collection of memories about events (real or imaginary), experienced directly or those about which knowledge is passed down from generation to generation through oral and written tradition and all other information channels" (1999:43). Barbara Szacka draws attention to the changeability and dynamics of social memory and the fact that it is a constant area of clashes and the mixing of different perspectives. Taking into account the recent past - and this is what will be of interest in the case of Zofia Rydet - collective memory comprises three elements: the memory of individuals about their own experiences, the memory of the community resulting from the personal experiences of many individuals and from officially communicated images of the past, and celebrations commemorating these events (Szacka 2006:44-45). In this case, the main analytical category is individual memory. Taking into account the above remarks, it is worth referring to the idea of communicative memory, proposed by Jan Assmann (2008:66).
Its content becomes what has been personally experienced and remembered as part of an individual biography, and told to others. It is a kind of shortterm memory (the limited life span of an individual), anchored in the immediate past and dependent on personal experiences and emotions (Krajewska 2016:23). This kind of memory was activated during the interviews dedicated to Zofia Rydet. Analyzing the interviews, the focus was primarily on what directly concerns Rydet in the context of her style of work, relations with others, and opinions expressed by her about photography, life, old age, and passing away. Thus, a kind of portrait was created based on the memory of those who knew her and had the opportunity to spend time with her and participate in her photographic expeditions. In many cases, these were long-term relationships, sometimes turning into friendships. The research focused on how Zofia Rydet was remembered and whether recurring themes or elements were revealed in this rich collection of memories, allowing the reconstruction of the artist's socially-preserved image. Also, it is these interviews that made it possible to look for the new, unknown, undiscovered Zofia Rydet. An excellent example of discovering what is situated next to the official image of the outstanding artist is the photo-essay based on the memoirs and photographs of Anna Beata Bohdziewicz (2017:49-67). Here, one can meet Rydet as a person full of sense of humor, distance to herself, but also as a person capable of establishing close, almost intimate contacts with her models. Such testimonies are extremely valuable for the biographically-oriented sociology.

\section{The organization of the study and the analytical procedure}

The main purpose of interviewing people who met Zofia Rydet was to find out how the artist was re- 
membered and what elements dominated this recorded experience of meeting her. In other words, the main research question was: is there a certain community of memories related to the artist? It should be explained that the level of familiarity of the respondents with Zofia Rydet varied from case to case, as it ranged from long-term friendships, through more or less formal acquaintances, to onetime but important - from the respondents' point of view - meetings. The collected material in the form of over twenty recorded free interviews allowed for an insight into how Rydet was remembered, but also gave an opportunity to look at the artist's life through unknown or poorly recognized biographical episodes. At this point, it becomes necessary to add one more comment, which concerns the biographical research procedure, but which is important also in relation to the material analyzed in this case. Piotr Filipkowski points out that when referring to the testimony of witnesses, "you are not looking for an answer to the question of how it really was, but about what and how it is remembered and told by the interlocutors, how they judge it, what they attribute the meaning to the events cited" (2006:15). When handling this type of material, one must remember about the subjectivity of memories and about the constant work that people do to give meaning to their experiences. Each of the memoirs about Zofia Rydet is also a fragment of the respondents' personal experiences, many a time assessed by them as biographically-significant. Already during the interviews, a set of recurring issues was identified. There were also questions and doubts, as well as attempts to clarify which required reference to other existing data, such as letters, recordings, and various texts. Several categories that emerged from the analysis of the interviews will be described in the article; the categories reflect the most frequently appearing threads resounding in the consecutive interviews. The procedure of isolating them was inspired by the grounded theory methodology (Strauss and Corbin 1990; Konecki 2000). The beginning of the analytical process was about systematically getting acquainted with the gradually accumulated material. Already at this stage, the preliminary coding of interviews and the separation of categories began. Each of them was saturated with assigning codes to individual categories. These were, respectively: relationships with people (both people related to the photographic environment and people photographed by Rydet), photography (recorded memories of the respondents regarding the artist's thoughts about the medium and the practice of photography), fieldwork (ways of organizing fieldwork, methods of establishing contacts with people - both met and photographed conversation, interaction strategies), home (the functioning of the artist's home as both a workplace and a meeting place for the artistic environment), and personality traits (openness, courage, repeatedly emphasized Zofia Rydet's extraordinary activity and vitality, diligence, discipline, and meticulousness in the creation of her works). In this article, the categories will be presented together with theoretical concepts that allowed the anchoring of the selected categories by referring to concepts such as mythologization, interactive ritual, and terrain. In order to deepen the possibilities of interpreting the categories, reference was also made to other data, including, inter alia, letters, interviews, publications, fragments of films in which Zofia Rydet spoke, or in which people who knew her recounted their experience. Interviews were given by artists, theoreticians, and critics of photography, as well as friends of Zofia Rydet, i.e those not directly related to the world of art and the photographic community. The vast majority of registrations were carried out in the interviewees' private homes, which was often 
accompanied by a presentation of photos and souvenirs related to Zofia Rydet that are in the possession of the interviewees. ${ }^{9}$ Since one of the results of the project carried out by the research team is the publication of a book containing the conducted and authorized interviews, the anonymization of statements would not make much sense. For this reason, in the article below, each quote from the interviews has been signed with its author's name. ${ }^{10}$ The article will describe the categories that make it possible to present Zofia Rydet as an artist while omitting those that characterized the environment in which she functioned, her home, and the workplace, which was extremely important to her, namely the darkroom. Therefore, the issues selected for the analysis herein relate to the artist's creative work and artistic attitude, her sphere of opinion about photography, and her method of working in the field.

\section{Rydet's artistic attitude and creative output}

When examining the photographic legacy of Zofia Rydet, it is difficult to avoid a simple question about how one person could create such a huge photo archive. What kind of hard, long, and constant work was required to complete these creations? What amount of internal discipline and determination did Rydet have so that she could make consecutive photographic series, prepare exhibitions, send her works abroad, organize field trips, develop negatives, and prepare prints? It is known today that

\footnotetext{
${ }^{9}$ The interviews were conducted by: Andrzej Różycki, Mariusz Gołąb, Karol Jóźwiak, Stefan Czyżewski, and Tomasz Ferenc. All the interviews have been recorded and transcribed with the respondents' consent. The interviews were published in the book edited by S. Czyżewski and M. Gołąb (2020)

${ }^{10}$ If a quoted part of an interview was not published in the book, the author asked for an individual consent to quote this fragment.
}

Rydet photographed intensely, but not compulsively. Looking at her photos, also those that remain in the form of developed and protected negatives, one can always reflect on the frame, but also think in terms of simultaneously created photo series. This is how Anna Beata Bohdziewicz characterizes the artist's photographic strategy:

She never took random pictures. She did not take pictures like photographers do, to have a good one. No. She was taking pictures to keep them in individual drawers, for individual projects that she had in mind. Sometimes several at the same time. (A.B. Bohdziewicz)

The above observation does not exclude a similar one, made by Krzysztof Cichosz about Rydet's constant desire to photograph. It is probable that one of the above-mentioned drawers contained documentation of the social life of the Polish photographic community.

Rydet always had to register. Never did I see her without her camera, maybe during later talks, in her flat, that camera was put away. Whenever she appeared she would always carry her camera on her chest, taking photos nearly every step she took. (K. Cichosz)

How can this compulsion to photograph be explained? Cichosz mentions a sense of mission, a deeply internalized inner conviction that photographing and documenting is necessary and important. Similar comments appeared in other interviews as well:

She said that time passing must be noted down. Then one can think what to do with it but if one doesn't note down, there is nothing left. (W. Jama) 
A similar way of thinking about the work of Zofia Rydet and her understanding of photography can also be found in the interview with Piotr Wołyński. According to this artist, Rydet distanced herself from the neo-avant-garde thinking and this way of using photography, which does not mean that she rejected it. However, as Wołyński emphasizes, the scientific and rationalist context of the neo-avantgarde was alien to her, because it resulted from a completely different outlook and way of thinking about the world:

The attitude of Zofia Rydet was derived primarily (...) from the point of view that was shaped in André Bazin's photographic thought, that was the embalming of time. It was something that brought an extra-rational element to imaging, above all it brought some kind of problems of mythology, myth, and existential problems to imaging. (P. Wołyński)

Rydet's first two series of photos, namely Little Man and Time of Passing-by, clearly show the artist's interests. At their center there is a person experiencing emotions. The consequence of this was the humanistic perspective and style of photography she adopted during the realization of these cycles. They also point to existential themes concerning childhood on the one hand and transience, old age, and the passage of time on the other. Her view of children was neither sentimental nor superficial. She saw in them little people, "with all the complicated multi-shape of experiences and reactions, both joyful and sad, even tragic" (Ligocki 1965). When she portrayed old people, in turn, her gaze was also devoid of slackness. Once Rydet took these pictures, she was still far from entering the period of biographical experience of old age. She had been, however, sensitized to the topic she was about to start exploring fourteen years later in the Sociological Record.
On the other hand, The World of Feelings and Imagination is a manifesto of thinking about photography in terms of myth and symbol. It is probably for this reason that Piotr Wołyński emphasizes that "for her, photography was something magical, it was the magic of the image." Not accidentally, therefore, he invokes the concept of André Bazin. According to this French theorist, from a psychological point of view, the history of fine arts is the history of similarity, the search for the most realistic forms. This need for embalming time became for him an essential feature of art, an attempt to "save existence by saving its external appearance" (Bazin 1963:10). According to the French theorist, photography was the culmination of this long process. Although its essence is realism, it often serves a deeper, metaphysical concept, freezing the image, opposing the passage of time and, finally, what the artist often repeated to be fighting death and passing away.

A fragment of the interview with Wojciech Prażmowski also seems to be important for understanding Rydet's creative attitude, as her way of thinking about photography is very close to Prażmowski. Here, again, there is this mythical sphere, something that remains beyond purely intellectual reflection and is based on intuition and deep faith in the role of photography, which for Zofia Rydet has become "a medium connecting the spiritual and material world" (Jóźwiak 2013:48). It was a world of absolute values, in which one cannot lie, and the act of photographing must be anchored in the sensitivity of the photographer.

I often visited Zosia, listened to such long, wonderful stories about love, about feelings, about sensitivity not to lose it, this repeated like the mantra: "take photos with your heart," which is outstanding to me today and what I repeat to my students. (...) She always 
talked about it, it was ringing in my ears all the time: "truth, truth, truth, there must be a real story here, you cannot lie." (W. Prażmowski)

In one of the artist's texts about her own work, one published in 1993, Rydet wrote that she had always wanted to create something that "would have the power to move people and make them think" (1993). This thought can be key to interpreting the artist's work, understood as a great photographic story about people: sometimes realistic, at other times oneiric or surreal, but always deeply humanistic. Rydet wanted to combine two aspects of the perception of reality and it seems that in her beliefs she could have been close to Susan Sontag, who was convinced that "thought is a form of feeling, and feeling is thinking" (2014:76).

Reading the interviews allows one to discover the increasingly complex picture of the artist. From the following stories there emerges a person who, as Krzysztof Cichosz emphasized, was extremely complex and internally complicated. What has been mentioned many times when describing Zofia Rydet was her great activity, diligence, and energy. In his interview, Józef Robakowski in several places emphasized her extraordinary vitality, openness, constant readiness to undertake new artistic tasks, but also a great willingness to continue the already started projects. Her artistic attitude showed signs of hyperactivity. All this, however, was accompanied by the awareness - growing with age - that it would not be possible to implement all the ideas into life.

Just like this she would produce more and more new cycles, which have not been realized, still in films, thousands of films. It was very typical for her, if it hadn't been for the fact she was getting older and lacked that energy she would have worked more. Always had that appetite for being a photographer. (J. Robakowski)
Her creative attitude, unusual activity, and diligence also resulted from what Waldemar Jama pointed out in his interview. Namely, Rydet was racing against time, so she wanted to use it as best and as intensively as possible. She could not afford to waste time. In the film by Andrzej Różycki, she said: "A human being should know that their life is limited. So that they have to take every hour into account, every day, because every day lost is actually priceless."11

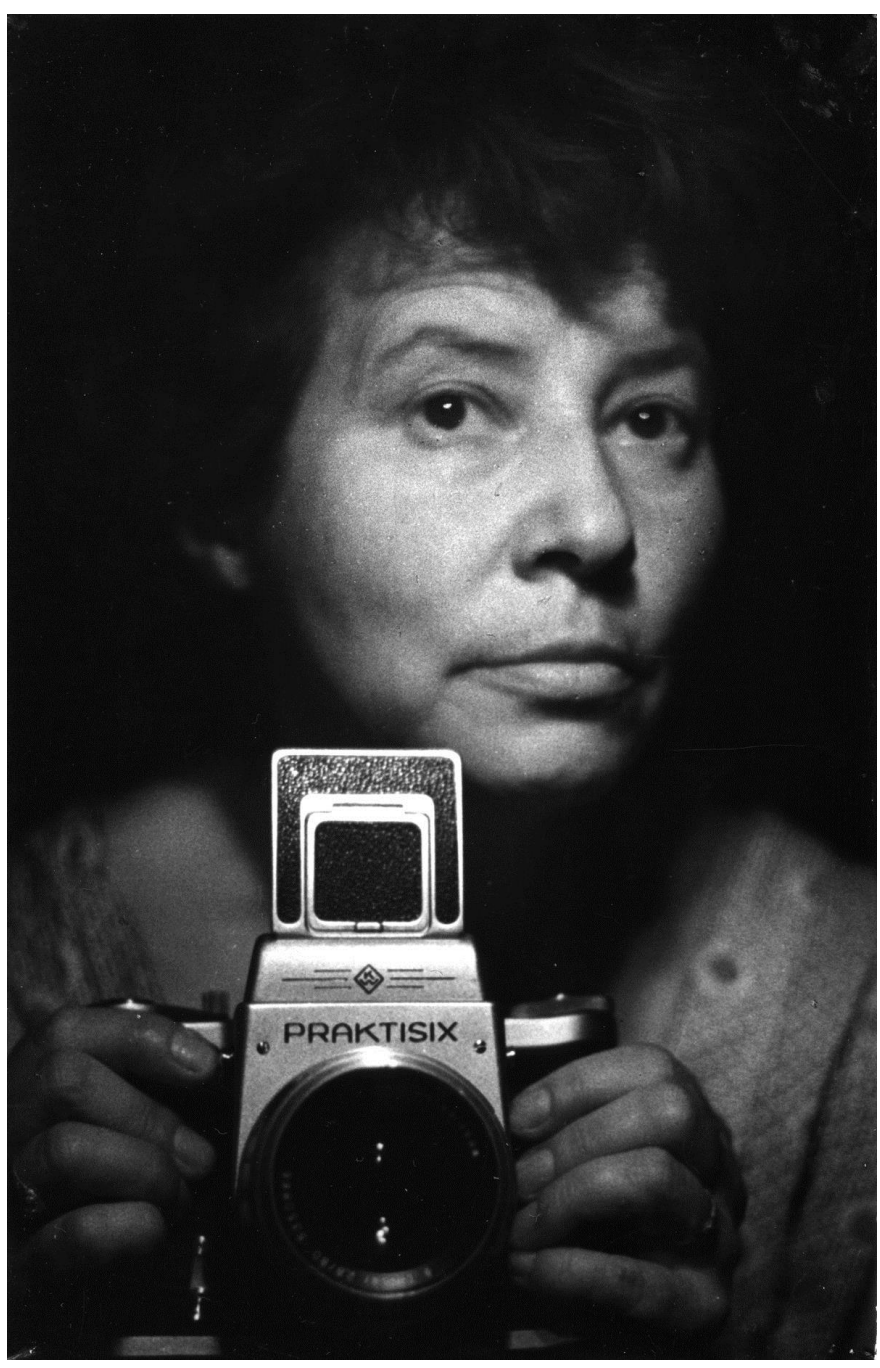

Source: Self-portrait, 1950s/1960s, from the archive of the Zofia Rydet Foundation

${ }^{11}$ The fragment comes from the film titled Nieskończoność dalekich dróg... 


\section{Photography and the mythologization of the artist}

By analyzing the interviews devoted to Zofia Rydet, one can create a portrait that allows a better understanding of the artist's life and work. However, equally interesting and useful from the sociological point of view is the study of the processes of mythologizing the attitude, tasks, and the role of the artist. The concept of a myth is understood here after Marian Golka, i.e. as "a form of consciousness characterized by a subjective sense of truthfulness with the impossibility of objectively verifying both the degree of its truth and falsehood" (1996:41). This interpretation places it beyond truth and falsehood, and beyond mystification and rationalization. According to Golka, it responds to the need of a social group to comprehend a given phenomenon. An important feature of a myth is that it is situated in the area of what is knowable, but also of what eludes cognition, or even what is completely beyond the possibilities of explication. It can, therefore, provide a sense of understanding where one can only rely on premises and imagination. An artist's fate, work, and legacy all seem to be an area not only provoking mythologization, but even forcing this process to some extent. The biographies of many artists contain numerous unexplained episodes; their works do not always lend themselves to exegesis, and their heritage changes its meaning with time. Thus, in order to learn and understand an artist's actions, it is easy to enter the area of myth. Characterizing the creative attitude of Zofia Rydet, Tomasz Tomaszewski draws attention to two key features of her artistic attitude, namely the autotelicity of motivation and absolute commitment.

The power of Zosia's photography stems from two things, two immensely important for a photographer features. First of all she was really truly motivated, not by desire to earn fame, money, success. Nothing of this kind. The other thing, she was seriously engaged in the process. Despite the lack of resources, the daily difficulties of the time, she did this work with incredible consistency; after all, she was a physically fragile woman, moving her camera on public transport in search of remote villages, places and people connected with them - the photographic themes of her Record. (T. Tomaszewski)

As a reporter and documentary filmmaker with extensive professional experience and creative output, Tomaszewski probably describes Rydet's attitude in an accurate way. However, there also appear mechanisms that are interesting from the perspective of the sociology of art. They are mentioned by Marian Golka in his examination of artistic myths. Each profession is associated with specific social perceptions, and each social world creates its own mythologies. Of all the various areas of professional activity, perhaps the social world of art is one of the most mythologized. Artists and other active participants in the field of artistic production create specific ideologies, thus legitimizing their actions and creating or maintaining the existing myths. Several of them were revealed in the analyzed interviews. Tomaszewski's statement contains traces of two such myths. The first one is the myth of selflessness, inherited from the Romantic era, praising the suffering, poor, often mad, and almost always unhappy artist. It carries the conviction, or even the expectation, that the artist should deal with art out of passion, honestly and selflessly, and the results of creative processes should not be converted into commercial success. Tomaszewski assumes that Zofia Rydet was alien to thinking in terms of artistic success, recognition, and even financial gratifications resulting from her creative work. However, one can also look at this matter from a different perspective. 
Firstly, depreciating the potential material benefits of the works seems unjustified, and it is contrary to the perfectly fine desire to make a living from one's own profession. Zofia Rydet sold her works, as she had contacts with collectors, art dealers, and museums that would purchase them. In the above-mentioned interview, Jerzy Lewczyński said that Rydet "was a woman for whom satisfaction from her artistic success was paramount." ${ }^{\prime 2}$ The desire to completely devote oneself to art does not mean giving up the desire to obtain various benefits from it, both material and symbolic, in the form of recognition and prestige. And prestige is the second important element that Rydet allegedly did not strive for. As I see it, however, it is exactly the opposite. Rydet made efforts to include her works in the collections of important, prestigious cultural institutions, and for this reason she donated many photographs to such important institutions as, e.g. MoMa (Museum of Modern Art in New York). Another one was the National Library in Paris, to which the artist donated a huge collection of her photographs. She did it on her own initiative, being aware that the survival of the legacy also depends on the collection of her works. ${ }^{13}$ Sometimes it is an institution that initiates the purchase of works, but sometimes it happens that the artist tries to include their works in a selected collection. Zofia Rydet herself made efforts to locate her photographs in such institutions. This proves her belief in the value of her own work and her knowledge of how the art world works. Rydet's desire to go beyond local art collections and the efforts associated with it only confirm the uniqueness of her creative strategies. The

${ }^{12}$ https://www.youtube.com/watch?v=rEX4FMCMNQo\&t=350s (accessed: 02.03.2019).

${ }^{13}$ Letters of Zofia Rydet are archived by the National Library in Paris and were confirmed by Karol Jóźwiak. They clearly prove that it was the artist who initiated the cooperation. desire for the work to survive is understandable, the actions taken for this purpose seem fully justified, and it probably makes no sense to place them in the area of a lack of interest or, rather, deliberate actions aimed at securing artistic achievements. It is worth exploring this issue, as it was important to Zofia Rydet and was raised, among others, in the story of Wojciech Prażmowski:

I remember such conversations, appearing quite often at the end of her life, these are the conversations from the 90s that: "Oh, all this will be flown in the garbage after my death (...). I just wanted one thing to stay, one thing. She took one sheet of paper out of the bookcase - it was a thank-you letter from the National Library in Paris, thanking you for donating the photo collection to the National Library. "This is what I am happy about," she said, "it is the most precious thing for me that they are in Paris, in the National Library. Because she offered them. She offered, not sold. (W. Prażmowski)

Zofia Rydet tried to locate her works in as many places as possible. In an interview conducted by Krystyna Łyczywek, the artist declared: “To be sure, I send my works to different places - I'm not stingy. If the bomb falls here, maybe not in Moscow and Rome."14 In another interview, Anna Kwiecień talked about Rydet's reaction to the purchase of her works by the photography department of the Museum in Gliwice:

I also know that she was happy, first, that her photos will be in the museum, and second, she just bought herself a color TV. It was so trivial, but she couldn't afford it back then in 1992. (A. Kwiecień)

\footnotetext{
${ }^{14}$ The complete interview is available at the Zofia Rydet Foundation's Website: http://zofiarydet.com/zapis/pl/pages/sociological-record/discussions/rozmowy-o-fotografii (accessed: 02.03.2019).
} 
Thinking about preserving one's own work is understandable, as are concerns about what might happen to it after the author's death. Many prominent filmmakers have experienced similar anxiety. It could result not only from the lack of people or institutions ready to take care of the creator's legacy, but also from what Arlie Hochschild calls "deep history" (2017:129). Getting to know it allows one to understand the views and actions of others, also when the analyzed actions seem incomprehensible or unjustified. It is precisely in the deep biographical history that one can find the fear of another irreversible loss. Jerzy Lewczyński wrote about it in a short biographical sketch, emphasizing the extremely dramatic nature of the experiences during the occupation (2005:13). In another text, he mentioned the arrest of Zofia's father and brother by the Soviets and how, after numerous efforts, both of them were bought back (Lewczyński 1999:13). In Andrzej Różycki's film, the artist says: "My childhood was very beautiful, very good. My father was rich, we had everything we needed, my mother didn't work, there was a lot of service. And then the whole tragedy began."15 Rydet experienced occupation, forced abandonment of her family home, and migration to the distant southern and western territories of Poland, where she moved several times. There does not seem to be any autobiographical record in which Rydet would refer to these experiences. However, there are some fragments of the story that make it possible to talk about this kind of experience in terms of trajectories. "The core of trajectory experience is the sense of the individual that he is under the control of forces independent of his will, the inability to control them and act freely, and in the peak phases - a sense of suffering, deep disorientation and separation from the world of others" (Rokuszewska-Pawełek 2002:79).

\footnotetext{
${ }^{15}$ From the film titled Nieskończoność dalekich dróg...
}

As Rydet's life came to an end, the vision of losing all her artistic output became real. Photography, as Lewczyński emphasized when recalling joint journeys and conversations, "changed her life and gave her satisfaction in making her dreams come true" (1999:16). The vision of losing it all must have been very disturbing to Rydet.

(...) she was afraid that all these negatives, all her work, (...) that it would all end up in the trash, that nothing would come of it. (B. Saucha)

The second thread undertaken by Tomaszewski, which also appears in other interviews, concerns Zofia Rydet's absolute focus on work and art. There are clues to the myth of suffering and sacrifice. In his reflections on the artist's mythologies, Andrzej Osęka writes that "the artist must suffer, this is what the legend requires" and then "he/she makes joy and relief out of his/her own pain and bitterness - for others" (1975:165). Tomaszewski mentions Rydet's numerous journeys, titanic work, and her steadfastness in the creation of the Sociological Record. All this is undoubtedly true; her enormous effort demands recognition and respect. The effect of the work is so stunning that Bohdziewicz probably expressed it best when talking about a psychedelic record, based mainly on the enormous strength of the author's psyche, but also on a kind of obsession and internal compulsion to continue the project. Urszula Czartoryska spoke in a similar vein by asking the right question: "So what is the role of the sociological adjective here, since there are more psychic sparkles between the model and the author that attract each other (...)" (1999:19). Coming back to the undisputed, fully committed dedication of Zofia Rydet, one must remember, however, that many assistants were present when Rydet was working on Record, and without them it would have been difficult for the 
artist to develop her project on such a large scale. It was mentioned, among other authors, by Waldemar Jama, a representative of the Silesian photographic community:

As far as I know, Zosia involved many people from all over Poland, who helped her a lot. For example, Ms Bohdziewicz. On the other hand, other members of our union, who had better photo studios, made copies of the negatives. (W. Jama)

It was also the case that the people who assisted Zofia Rydet very often accompanied her during the legendary field trips. As a rule, this help consisted of arranging a means of transport or being a guide in an area that Rydet did not know. When examining this aspect, it is worth asking oneself to what extent it would have been possible to create the Record in the form in which it is known today it without the support of all the people involved, ready to help at various stages of the process. Estimating the scale of participation of persons supporting the artist would be a difficult task, or even an impossible one. What is certain, however, is that the artist's need to work with someone who could become an assistant in the fieldwork increased with age. Bogusław Saucha, who himself traveled with Zofia Rydet many times, also mentions this aspect:

Zosia was quite ill, she had a spine disease and suffered from mobility limitations. But that didn't stop her from her trips at all. (...) She traveled around the nearby villages of Gliwice, but traveled either with one of the young students, whom she had a wreath around, or with a friend. (B. Saucha)

This part of Rydet's story brings one closer to another important category in her life, namely fieldwork and meetings with photographed people. The collected stories make it possible to reconstruct what one can call the interactive ritual of Zofia Rydet. Perhaps this explains the secret of the Sociological Record's success.

\section{Fieldwork}

When thinking about Zofia Rydet and the photos she took, it is impossible not to reflect on the style and method of working in the field. The foundation of her success and effectiveness was her talent to establish contacts and to carry on a conversation, evoking the sympathy and interest in the people she met. In this case, interviews with respondents who participated in this type of plein-air are particularly valuable. Their memories allow a better understanding of the phenomenon of the Record. However, before I proceed to the report on Rydet's fieldwork, it is worth considering an accompanying idea, which did not involve documenting everything but, rather, was based on a thorough selection. It is not surprising, because entering the field with a research intention or in the open air for the same reason is always connected with specific expectations and, therefore, always intentional and planned activities. In the open air, the artist wants to produce art, similarly to how the scientist wants to generate knowledge in the field. Simply put, they both want to get something out of the situation. In both cases, this type of activity can be a source of satisfaction on the one hand, and disappointment on the other. This is, among other things, due to the fact that the terrain exists independently of the agents, i.e. neither the researcher nor the artist can control it; on the contrary, the terrain exercises considerable control over those who try to explore it (Fatyga 2011). Incidentally, it is worth noting that, to a large extent, the documentary photographer finds themselves in an interesting position between the artist and the field researcher. Entering the field is, therefore, about entering an area 
of imagination, ideas, expectations, fears, and hopes. It is always associated with an attempt to master such a space, with the willingness to use it for one's own purposes, to transform it into something describable or suitable for showing in the form of a film or a photograph, or presenting it in the form of a research report. Finally, this kind of confrontation with reality always entails the risk that the encountered people will not submit to the will of the researcher or scientist, will not want to cooperate, and will be even less willing to reveal their world to strangers. Taking into account all the difficulties associated with this type of work, what Zofia Rydet managed to achieve is unusual and unique. Like everyone who goes into the field, Rydet was looking for something out there. She repeatedly emphasized the importance of the meetings with the protagonists of her photographs. In the text prepared for the Museum in Gliwice, she wrote: “These meetings with people, still new and so interesting, gave them strength. At the same time, they taught me a new philosophy, a new valuation, attitude towards the most important matters of life and death."16At the same time, her choices of what to photograph were dictated by preliminary assumptions related to their selection, as pointed out by A. B. Bohdziewicz:

When Ms. Zofia was walking through the village, it was not, for example, that she would photograph all the old cottages, but she photographed those she liked, in which she thought that something interesting would be there. (A.B. Bohdziewicz)

Therefore, Zofia Rydet was looking for houses that intrigued her in some way, and in which she expected to find people of interest to her. Looking at her photos, one can see that the frequently used key was the se-

\footnotetext{
${ }^{16}$ http://zofiarydet.com/zapis/pl/pages/sociological-record/notes/ o-swojej-tworczosci (accessed: 17.08.2020).
}

lection of huts and farms that resisted various kinds of modernization, to which new aesthetics did not yet arrive, and whose inhabitants did not want to become like city residents. The artist chose places where the village resembled, at least visually, that which she might have remembered from before the pre-war times. Such a statement must remain an unverifiable hypothesis based solely on the photographs she took.

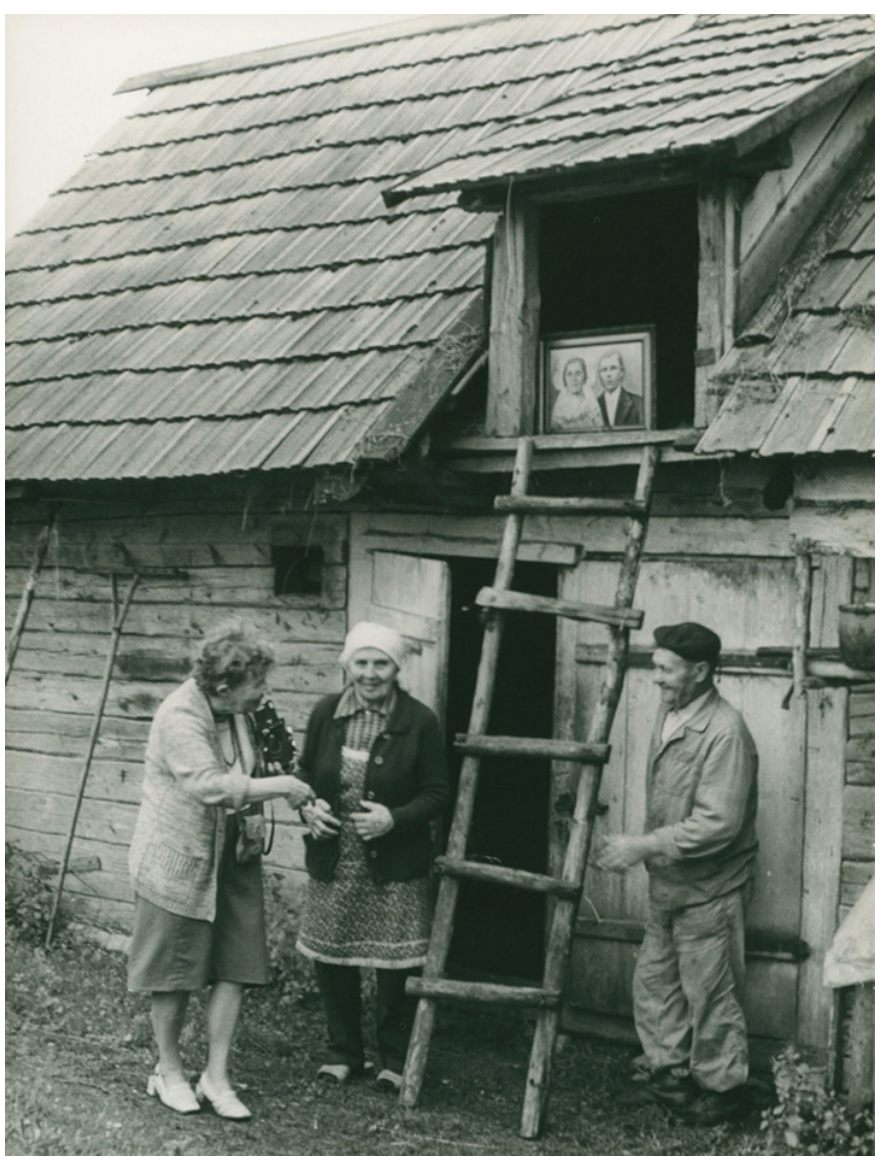

Source: Zofia Rydet around the time of working on her project Sociological Record, 1970s/1980s, author unknown, from the archive of the Zofia Rydet Foundation

Without any doubt, she was focusing on places that she felt were about to disappear. In order to be able to take pictures, the artist developed an effective interaction scheme. The fullest description of this type of situation can be found in the interview given by Anna Beata Bohdziewicz. In August of 1988, herself 
and Zofia Rydet spent two weeks visiting the villages around Rabka.

(...) here is what we did. We would go through the village and then let's say there is a cottage she would like. She had this feeling there was something that she would find interesting. So we are coming in, the entrances are different, back then the estates were not always fenced so sometimes you have a wicket and sometimes you have to ring a bell, sometimes you just enter right from the road, so we enter, and that is the way it was, August but still warm, let's say summer, doors most often open so we just knock on that door, Mrs. Zofia goes first, then we follow. Knock, knock, "Good morning, can we come in?". So either someone goes out saying why who what for. "We want to take photos" she would use the plural (...). She would not say "I would like to," she would not use conditional, just straight forward: we want and she would add immediately that we are not paying for these photos. There were all sorts of reactions: what? Why? What is it about? By this time we are already inside the house, in the kitchen or even better. We see this parade chamber. " it is so beautiful here, so beautiful here." "But where? What are you talking about? I am not even dressed," "no it is beautiful" and that was it, she was a hypnotizer. She was a kind of a despot and had these eyes, and this charm, and she would hypnotize. If she got you, you were hers. Caught in the net, end of story, one did all she wanted, no discussion. It was a lot if she allowed someone to wear a clearer apron. So this is how it all looked like. (A.B. Bohdziewicz)

The above testimony says a lot about the method used by Zofia Rydet, in which the ability to establish contact was combined with a delicate form of pressure exerted on the householders. The description of this method is developed in the story of Anna Kwiecien, who did not participate in the fieldwork, but learned it from the artist herself. It could be said that a combination emerged in which pressure and charm, when applied in the right proportion, gave the effect that Rydet wanted.

This is what she told me, that when she entered the house (...) it was impossible to ask her out. Of course, it did happen that she failed. She was first taming her object, saying nice things, making compliments: Oh, how beautiful! You look so beautifully! It is so beautiful here! And she got them, she tamed them. Anyway, she was a very open person. And this is when she took these photos of hers. (A. Kwiecień)

Both accounts clearly show a repetitive pattern, the strength of which was based on ritualism. Erving Goffman defines ritual as actions "through which, due to their symbolic aspect, the action shows to what extent it deserves respect and to what extent then, others deserve it" (2006:19). It is crucial here to establish the place of all parties in the interactive ritual in such a way that it is generally acceptable. Looking at Rydet's photos, and knowing the account of these meetings, one can see that the realization of the said idea was possible only because she was able to control the situation and direct it toward taking the photo. Iwona Kurz points out that the characteristic tension between a meeting and instrumentalization is present in many frames of the Sociological Record. "Looking for what is valuable to her heroes, she does not give them the field - it is she who decides how and in what to pose, for example breaking away with the festiveness of a photographic gesture, against the expectations or needs of her models" (Kurz 2015). Did Rydet really break with the festivity of this gesture, or on the contrary, did she make it the axis of the whole meeting? If one selects the second option, one must nevertheless recognize that Rydet defined this festivity in her own way. In order to grasp it, one should refer once again to the already cited text prepared for the Museum in Gliwice, in which the artist writes: "A man who was supposed to be only 
an element, but was the most important, at the same time looking into the lens creates a very strong thread between us, model-camera-photographer. The model was aware, looking straight into the lens, of the importance of the moment, this kind of capture, of retaining his personality specific to him, of ennobling him to some symbol, although he himself was not great" (Rydet 1993). Understanding the importance of this gesture came directly from how Rydet defined photography and from how she perceived the essence and meaning of her work in the field.

The artist described the style of work she adopted several times in various texts, revealing the usual course of meetings with people who posed for her photos. In the already quoted interview conducted by Krystyna Łyczywek, there is an interesting fragment on this issue:

"Entering the apartment I look around carefully and I see something beautiful, something special so I praise loud it right away. The owner is caught up in it so I take the first photo. Everybody has something at home that they find the most precious. If I manage to identify that object then that person is already mine. And this is the moment I take advantage of. I ask them to be seated (very often married couples) in front of the main wall, this most interesting, most decorated one and I shoot. I photograph."17 Also, the film made by Wiesław Głowacz, titled The Portraits: Zofia Rydet, shows her describing the ritual of a handshake. This is how she puts it: "I realized that if I shake hand with this man he will never refuse to me and truth be told these people are becoming close."18 Tomasz Tomasze-

$17 \mathrm{http} / /$ zofiarydet.com/zapis/pl/pages/sociological-record/discussions/rozmowy-o-fotografii (accessed: 12.08.2020).

${ }^{18}$ From the film by Wiesław Głowacz, available at: http://zofiarydet.com/zapis/pl/pages/sociological-record/media/portrety (accessed: 12.08.2020). wski draws attention to the artist's commitment to rural areas and her talent to talk to their inhabitants. Rydet, a pre-war graduate of the School of Farming in Snopków, understood these people and was genuinely interested in their lives. She also had some kind of charisma, owing to which she was able to convince thousands of people to let themselves be photographed. Tomaszewski describes it as follows: "She also had something magical about her, which made people attractive to herself. It is not easy to enter someone's home like this."

All of the above into account, Zofia Rydet developed what today can be called an interactive scheme that she successfully used throughout the years of working on the Sociological Record. The collection of photographs created over 12 years proves the effectiveness of this strategy. One of its elements was the persuasive use of something that can be tentatively described by the papal argument. Bogusław Saucha, a friend of the artist, who participated in many photographic expeditions, reports it very clearly:

(...) it was practical for her because it was the key to the hearts of people houses of whose she wanted to enter. Some didn't want her to take photographs, especially in the village, poor host in her dirty apron, bare footed. But when Zosia said she was making those photos for the Pope so that he sees her too, the door were wide open. People would sit in central part of their houses because that was the idea to seat them in their natural environment, so they would look straight in the camera, and she was taking a photo. (B. Saucha)

It should be added that it was not only a rhetorical trick calculated toward the effect, as evidenced by the letter to Krystyna Łyczywek from July 18, 1983, in which Rydet describes her stay in Rabka. She also writes about her decision to photograph for the Pope: 
"Now, however, I am doing primarily for the Holy Father - this is my task, I want to give these hundreds of people to him, so that he can see how the nation loves him. And now there are almost altars in every house. If only I had enough strength to bring it all up later."19 Therefore, it is possible that a strong impulse to start working on the Record was the beginning of the pontificate of John Paul II. This can be confirmed by the fact that Rydet started taking pictures for this series in the same year.

Finally, it is worth picking up one more thread related to fieldwork, which, at the same time, fits in with the earlier considerations on the mythologization and demythologization of the artist. Taking into account the huge number of meetings that Zofia Rydet had to initiate, it is not surprising that there were cases of not granting permission to take photos. The interviews demonstrate that these were not frequent, but they did occur, and in the collected material there were also such testimonies. One of them reads as follows:

Once one lady did not let us come in her house, she was standing in the doorway; I also have her photographed, very neat, wearing her headscarf, a hen right next to her; Zosia was explaining to her the whole thing, she mentioned the Pope but that lady said no anyway. One denial in two weeks. (A.B. Bohdziewicz)

\section{Concluding remarks}

The collected interviews had provided a lot of valuable material, from which merely a few threads were selected for the purposes of this article. What was omitted concerns, among other things, the extremely interesting accounts of Zofia Rydet and Jerzy Lew-

19 http://zofiarydet.com/zapis/pl/pages/sociological-record/letters/krystyna-lyczywek-18-07-1983 (accessed: 12.07.2020). czyński. These two outstanding artists and friends, living in Gliwice, held an intense discussion about photography and art. Also, the interviews provide a lot of information about the photographic environment in which Rydet was actively involved. A colorful description of such a functioning emerges from these fragments; using the term by Pierre Bourdieu, it is about "the field" (Bourdieu 2001; Matuchniak-Kasuska 2010) of photographic symbolic production, its diversity, activity, and dynamics. Furthermore, the interviews contain very interesting threads about the contemporary functioning of photography as such. Finally, various interpretations of the individual cycles created by Zofia Rydet are also revealed, with a strong thesis regarding the necessity of reading the artist's output as a whole, and not as separate sets. What image of Zofia Rydet emerges from these collected stories? Krzysztof Cichosz emphasizes that the artist "was internally very complex and it can be seen from many threads of her work." It is worth refraining from giving in to the image of Zofia Rydet as an elderly lady traveling through Polish villages with a camera around her neck. In fact, her actions were marked by a kind of artistic madness in the non-impregnated form. Writing about great Christian mystics, Jean-Noël Vuarnet sees the uniqueness of their madness, which he describes as "not impregnated" (2003). It is synonymous with the madness of brilliant artists such as Dostoyevsky, Kafka, or Rimbaud, for whom it was a pretext and the cause of deep experiences and visions, as a result of which outstanding works of art were created. "Excessive thinkers, extreme poets, mystical patients - the great experimenters have always been madmen beyond madness" (Vuarnet 2003:23). Therefore, eminent mystics remain faithful to their dogmas, form, and goals. However, Dostoyevsky does not go beyond the novel, van Gogh does not go beyond the painting frame, and the holy mystics do not go beyond their faith, while 
Rydet goes beyond the photographic frame. Madness becomes necessary to break free from the supremacy of reason, and at the same time it does not need any diagnostics and treatment. The situation is different when it comes to impregnated madmen, as they remain in the domain of medicine and they are identical to their madness, for which they cannot go. Zofia Rydet was faithful to her medium and the goals she had set herself. She expressed it clearly in the film by Andrzej Różycki: “I cannot live without photography. Because I have nothing else but it. Just this photo. It is now my greatest passion, my greatest love, well, the greatest of all that I have. ${ }^{\prime 20}$ Moreover, the fact that she was consistent in her attitude is evidenced by the text she had written 14 years earlier. "I don't like writing about myself: I prefer my works to speak about my artistic credo. I can only say that photography is my love, possession, fascination and obsession. Photography is my work and my leisure, it takes away every thought, but it also gives me strength to live" (Rydet 1976:10). Considering the two above-mentioned statements, Tomasz Tomaszewski is probably right when he says that "Lewczyński said I changed my life into a photograph, but maybe in relation to Zofia Rydet it is more adequate." Her madness was about devoting her life to photography in its fullest and about being absolutely committed to it, as evidenced by both her biography and her work. In the materials about Zofia Rydet - those collected during the research and those recorded earlier - there appears the conviction that most narrators believe that the artist was outstanding. When referring to the typology of the personality developed by Florian Znaniecki, the described stories reveal something that the eminent sociologist called "supernormality," i.e. inexplicable individual eminence. "Abnormality occurs ... when an individ-

${ }_{20}$ Taken from the film titled Nieskończoność dalekich dróg. Podpatrzona i podstuchana Zofia Rydet A.D. 1989, directed by A. Różycki, Wytwórnia Filmów Oświatowych, Łódź, 1990. ual in a given role, once ingested into it, does more or better than the personal pattern used in such roles by normal people" (Znaniecki 2001:268). According to Znaniecki, such a human being is able to enrich cultural systems, gather social circles around them, and become a personal role model. In the social memory of people associated with the world of art and photography, Zofia Rydet has remained someone "supernormal," i.e. completely devoted to her work and passion and fully committed to her role. ${ }^{21}$

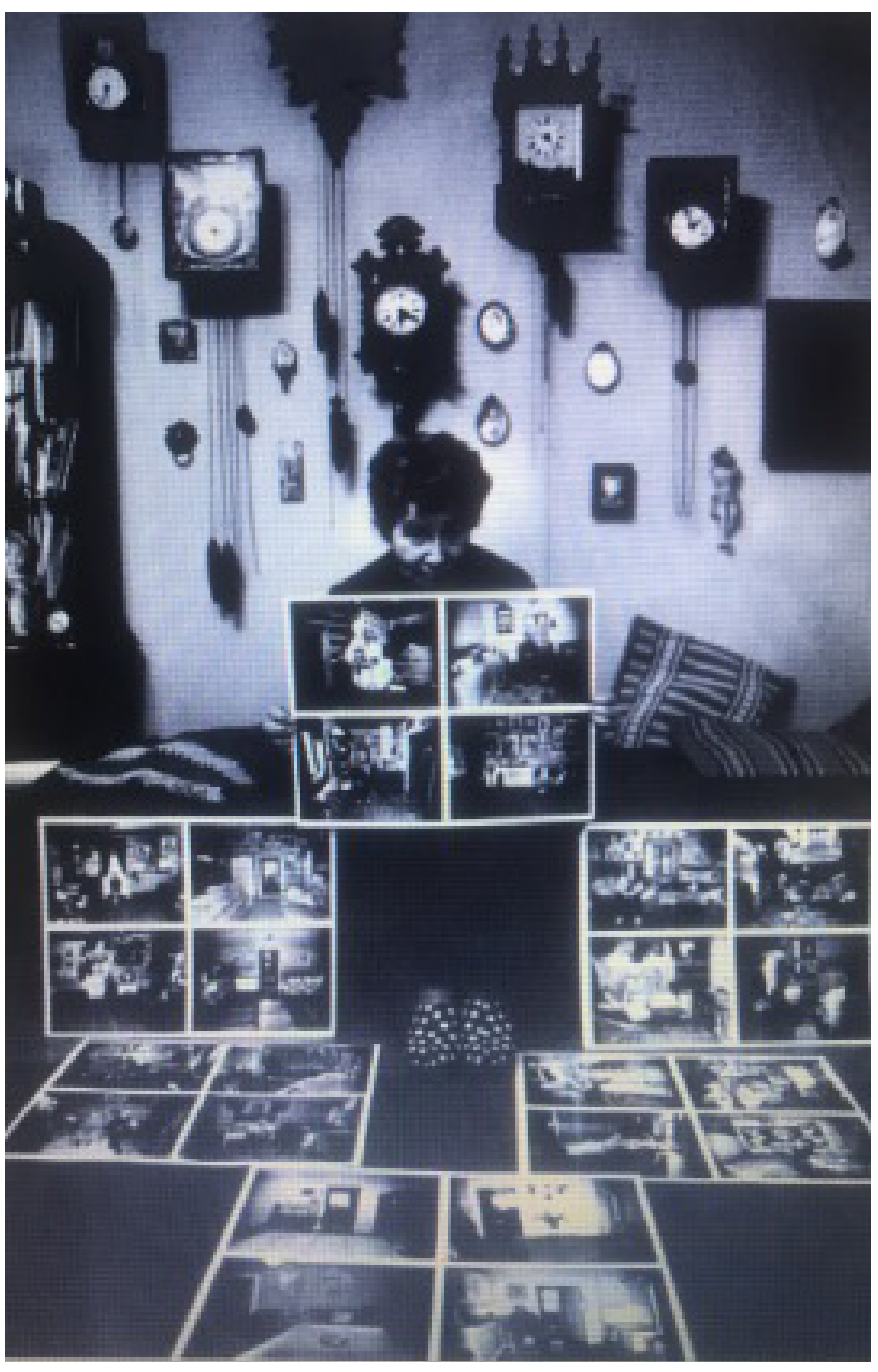

Source: Zofia Rydet at home, with the boards with the Sociological Record; author unknown, from the archive of the Zofia Rydet Foundation

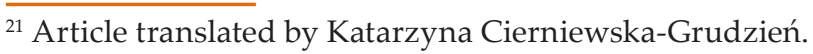




\section{References}

Andruchowycz, Jurij. 2019. Kochankowie Justycji. Wroclaw: Wydawnictwo Warstwy.

Assmann, Jan. 2008. Pamięć kulturowa. Pismo, zapamiętywanie i polityczna tożsamość w cywilizacjach starożytnych. Warsaw: Wydawnictwo Uniwersytetu Warszawskiego.

Bazin, Andre. 1963. "Ontologia obrazu fotograficznego." Pp. 9-17 in Film i rzeczywistość. Wybór tekstów. Warsaw: Wydawnictwa Artystyczne i Filmowe.

Bohdziewicz, Anna Beata. 2017. "Wanderings with Zofia Rydet." Pp. 49-67 in Object Lessons. Zofia Rydets Sociological Record, edited by K. Pijarski. Warsaw: Museum of Modern Art in Warsaw.

Bourdieu, Pierre. 2001. Reguly sztuki. Geneza i struktura pola literackiego. Cracow: Wydawnictwo Universitas. Czartoryska, Urszula.1999. In Zofia Rydet. Fotografie. Lodz: Muzeum Sztuki w Łodzi.

Dziewit, Jakub and Adam Pisarek. 2020. Ocalać. Zofia Rydet a fotografia wernakularna. Lodz: Wydawnictwo Uniwersytetu Łódzkiego.

Elias, Norbert. 2006. Mozart. Portret geniusza. Warsaw: Wydawnictwo W.A.B.

Fatyga, Barbara. 2011. “Teren.” In Stownik Teorii i Metodologii Badań Kultury. Retrieved April 12, 2021 (http://ozkultura.pl/ wpisy/183).

Ferenc, Tomasz. 2014. "Ambiwalencja kategorii 'sukcesu' na przykładzie opowieści polskich artystów emigrantów." Sztuka i Dokumentacja 11:91-100.

Filipkowski, Piotr. 2006. “Historia mówiona i wojna." Pp. 14-35 in Wojna. Doświadczenie i zapis. Nowe źródła, problemy, metody badawcze, edited by S. Buryła and P. Rodak. Cracow: Universitas.

Goffman, Erving. 2006. Rytuat interakcyjny. Warsaw: PWN.

Golka, Marian. 1996. Atrakcyjność mitu. Retrieved March 02, 2019 (https://www.nck.pl/upload/archiwum_kw_files/artykuly/2._ marian_golka__atrakcyjnosc_mitu.pdf).

Golka, Marian. 2009. Pamięć społeczna i jej implanty. Warsaw: Wydawnictwo Naukowe Scholar.
Gołąb, Mariusz and Stefan Czyżewski, eds. 2020. Zofia Rydet po latach. 1978-2018. Lodz: Wydawnictwo Uniwersytetu Łódzkiego.

Hochschild, Arlie. 2017. Obcy we własnym domu. Gniew i żal amerykańskiej prawicy. Warsaw: Wydawnictwo Krytyki Politycznej.

Jóźwiak, Karol. 2013. Zofia Rydet. Inwentaryzacja wizerunków. Cracow: Fundacja im. Zofii Rydet, Katowice: Muzeum Śląskie w Katowicach.

Jóźwiak, Karol, Tomasz Ferenc, and Andrzej Różycki. 2020. Zapisy pamięci. Historie Zofie Rydet. Lodz: Wydawnictwo Uniwersytetu Łódzkiego.

Konecki, Krzysztof. 2000. Studia z metodologii badań jakościowych. Teoria ugruntowana. Warsaw: Wydawnictwo Naukowe PWN.

Krajewska, Malwina. 2016. Buddyzm Diamentowej Drogi. Narracje o początkach. Bydgoszcz: Oficyna Wydawnicza Epigram.

Kurz, Iwona. 2015. Nie wyrzucajcie tego wszystkiego. Retrieved August 06, 2020 (https://www.dwutygodnik.com/artykul/6229-nie-wyrzucajcie-tego-wszystkiego.html).

Lewczyński, Jerzy. 1999. Zosia ..., Zofia Rydet. Fotografie. Lodz: Muzeum Sztuki w Łodzi.

Lewczyński, Jerzy. 2005. "Zofia Rydet - szkic biograficzny." Pp. 13-18 in Socjologiczność fotografii Zofii Rydet, edited by B. Panek-Sarnowska. Zielona Gora: Lubuskie Towarzystwo Fotograficzne.

Ligocki, Alfred. 1965. Wstęp do albumu Mały człowiek. Warsaw: Wydawnictwo Arkady.

Osęka, Andrzej. 1975. Mitologie artysty. Warszawa: PIW.

Matuchniak-Krasuska, Anna. 2010. Zarys socjologii sztuki Pierre'a Bourdieu, Warszawa: Oficyna Naukowa.

Rokuszewska-Pawełek, Alicja. 2002. Chaos i przymus. Trajektorie wojenne Polaków - analiza biograficzna. Lodz: Wydawnictwo Uniwersytetu Łódzkiego.

Rydet, Zofia. 1976. Tekst autorski towarzyszący zdjęciom in Fotografia 1:10.

Rydet, Zofia. 1993. Zofia Rydet o swojej twórczości. Gliwice: Muzeum w Gliwicach. 
Sontag, Susan. 2014. Myśl to forma odczuwana. Cracow: Wydawnictwo Karakter.

Strauss, Anselm and Juliet Corbin. 1990. Basics of Qualitative Research: Grounded Theory Procedures and Techniques. Thousand Oaks, CA: SAGE.

Szacka, Barbara. 2006. Czas przeszły, pamięć, mit. Warsaw: Wydawnictwo Naukowe Scholar.
Szpociński, Andrzej. 1999. "Pamięć zbiorowa a mass media." Kultura Współczesna 2:43.

Vuarnet, Jean-Noel. 2003. Ekstazy kobiece. Gdansk: słowo, obraz terytoria.

Znaniecki, Florian. 2001. Ludzie teraźniejsi a cywilizacja przyszłości. Warsaw: Wydawnictwo Naukowe PWN.

\title{
Citation
}

Ferenc, Tomasz. 2021. "Remembered: Zofia Rydet in the Biographically-Oriented Perspective of the Sociology of Art." Przeglad Socjologii Jakościowej 17(3):206-225. Retrieved Month, Year (www.przegladsocjologiijakosciowej.org). DOI: https://doi. org/10.18778/1733-8069.17.3.11

\section{Zapamiętana. Zofia Rydet w perspektywie biograficznie zorientowanej socjologii sztuki}

\begin{abstract}
Abstrakt: Zofia Rydet jest jedną z najwybitniejszych polskich, a nawet europejskich artystek drugiej połowy XX wieku. Pozostawiła po sobie ogromną spuściznę twórczą, ale jej biografia pod wieloma aspektami wciąż pozostaje tajemnicą. Pamięć o wielkim artyście/artystce jest często mitologizowana, a interpretacja dzieła po jego/jej śmierci zaczyna odrywać się od pierwotnych intencji twórcy. Są to procesy niezwykle interesujące dla historyków sztuki i socjologów. Można badać je, przyjmując metody biograficznie zorientowanej socjologii sztuki. W artykule wykorzystano niektóre z nich: analizę istniejących dokumentów, badania archiwalne oraz wywiady. Analiza zebranego materiału pozwoliła wskazać, w jaki sposób Rydet zapamiętali ci, którzy mieli okazję poznać ją, towarzyszyli jej podczas wypraw w teren, prowadzili z nią rozmowy o sztuce i fotografii. Celem takich badań jest próba lepszego poznania artystki, zrozumienia jej twórczości i funkcjonowania społecznego w określonych czasach i środowiskach.
\end{abstract}

Słowa klucze: artysta, fotografia, sztuka, biografia, praca w terenie, mitologizacja 